\title{
18 Years of Medication-Related Osteonecrosis of the Jaw (MRONJ) Research: Where Are We Now?-An Umbrella Review
}

\author{
Roberto Sacco ${ }^{1,2, *(\mathbb{D})}$, Monica Diuana Calasans-Maia ${ }^{3}{ }^{(}$, Julian Woolley ${ }^{4}(\mathbb{D}$, Oladapo Akintola 5 , \\ Carlos Fernando de Almeida Barros Mourão $\left.{ }^{3}{ }^{(}\right)$, Vittorio Moraschini ${ }^{3}$, Evgeny Kushnerev ${ }^{1}$, Alessandro Acocella ${ }^{6}$, \\ Olamide Obisesan ${ }^{5}$ and Julian Yates ${ }^{1}$
}

Citation: Sacco, R.; Calasans-Maia, M.D.; Woolley, J.; Akintola, O.; de Almeida Barros Mourão, C.F;; Moraschini, V.; Kushnerev, E.; Acocella, A.; Obisesan, O.; Yates, J. 18 Years of Medication-Related Osteonecrosis of the Jaw (MRONJ) Research: Where Are We Now?-An Umbrella Review. Appl. Sci. 2021, 11, 8818. https://doi.org/10.3390/ app11198818

Academic Editor: Gaetano Isola

Received: 31 August 2021

Accepted: 16 September 2021

Published: 23 September 2021

Publisher's Note: MDPI stays neutral with regard to jurisdictional claims in published maps and institutional affiliations.

Copyright: (c) 2021 by the authors. Licensee MDPI, Basel, Switzerland. This article is an open access article distributed under the terms and conditions of the Creative Commons Attribution (CC BY) license (https:/ / creativecommons.org/licenses/by/ $4.0 /)$.
1 Oral Surgery Department, Division of Dentistry, School of Medical Sciences, The University of Manchester, Manchester M13 9PL, UK; evgeny.kushnerev@manchester.ac.uk (E.K.); julian.yates@manchester.ac.uk (J.Y.)

2 Oral Surgery Department, King's College London, London WC2R 2LS, UK

3 Oral Surgery Department, Dental School, Fluminense Federal University, Rio de Janeiro 24020-140, Brazil; monicacalasansmaia@gmail.com (M.D.C.-M.); mouraocf@gmail.com (C.F.d.A.B.M.); vitt.mf@gmail.com (V.M.)

4 Oral and Maxillofacial Surgery Department, Northwick Park Hospital-London North West University Healthcare NHS Trust, London HA1 3UJ, UK; julianwoolley@gmail.com

5 Oral Surgery Department, King's College Hospital, London SE5 9RS, UK; dapoakintola@nhs.net (O.A.); oobisesan@nhs.net (O.O.)

6 Private Practice, 50129 Florence, Italy; alessandroacocella@yahoo.it

* Correspondence: roberto.sacco@manchester.ac.uk; Tel.: +44-(0)20-3299-32496

Abstract: Background: Osteonecrosis of the jaw (ONJ) is a condition affecting patients exposed to medications used to treat benign and malignant conditions of bone tissue. Many studies have highlighted that ONJ is a severe condition, which is very challenging to manage, especially in individuals with oncologic disease. The aim of this umbrella review is to analyze all available interventional and non-interventional systematic reviews published on medication-related osteonecrosis of the jaw (MRONJ) and summarize this evidence. Material and methods: A multi-database search (PubMed, MEDLINE, EMBASE and CINAHL) was performed to identify related multi-language papers published from January 2003 until June 2021. An additional manual search was also performed in systematic review registries (PROSPERO, INPLASY, JBI and OFS) to identify possible missing reviews. Data were extracted from relevant papers and analyzed according to the outcomes selected in this review. Results: The search generated 25 systematic reviews eligible for the analysis. The total number of patients included in the analysis was 80,840 . Of the reviews, $64 \%(n=16)$ were non-interventional and $36 \%(n=9)$ were interventional. Study designs included case series $20.50 \%$ $(n=140)$, retrospective cohort studies $12.30 \%(n=84)$ and case reports $12.20 \%(n=83)$. It was unclear what study design was used for 277 studies included in the 25 systematic reviews. Conclusions: The data reviewed confirmed that the knowledge underpinning MRONJ in the last 20 years is still based on weak evidence. This umbrella review highlighted a widespread low-level quality of studies and many poorly designed reviews.

Keywords: osteonecrosis; medication-related osteonecrosis of the jaw; systematic review; umbrella review; evidence-based medicine

\section{Introduction}

Medication-related osteonecrosis of the jaw (MRONJ) is an irreversible adverse event related principally to antiresorptive medications (e.g., bisphosphonates and receptor activator of nuclear factor Kappa-B ligand inhibitors) and angiogenesis inhibitors [1,2]. These types of drug therapies are used for the treatment of the skeletal manifestation of malignancies and/or bone metastases, and in the management of osteoporosis, Paget's disease or hypercalcaemia $[3,4]$. 
Since the first clinical study of bisphosphonate-related osteonecrosis of the jaw (BRONJ) was published in 2003, a growing number of scientific articles have documented similar complications connected with other medications, such as monoclonal antibodies, tumor necrosis factor- $\alpha$ (TNF- $\alpha$ ) inhibitors drugs and recreational drugs [5-7]. Due to the number of medications linked with the development of ONJ, in a 2014 positional paper, the American Association of Oral and Maxillofacial Surgeons (AAOMS) developed and defined the medical term MRONJ [8].

This AAOMS position paper outlined that patients should be considered to have MRONJ if all of the following three characteristics are present:

(1) Current or previous treatment with antiresorptive or antiangiogenic agents; exposed bone or bone that can be probed through an intraoral or extraoral fistula in the maxillofacial region that has persisted for longer than 8 weeks;

(2) No history of radiation therapy to the jaws or obvious metastatic disease to the jaws [8].

Patients often present with exposed bone associated with a sequela of symptoms: pain, swelling, infection, tooth/teeth mobility, neuropathic pain and in some cases, pathological fracture [8]. Interestingly, approximately $25 \%$ of patients present with the aforementioned catalogue of symptoms without frank bone exposure [9].

The pathogenesis of MRONJ remains unclear, however a number of risk factors have been identified that are associated with an increased likelihood of MRONJ development. These risk factors have been recognized in multiple independent studies and include the potency and route of administration of the antiresorptive agent (intravenous bisphosphonate vs. oral), the underlying disease (cancer vs. osteoporosis), the duration and cumulative dosage of antiresorptive therapy, dentoalveolar surgery and dental infections [10-14]. The incidence of MRONJ can also vary based on other factors such as medical history, drug therapy, duration of therapy and type of dental treatments [8]. Researches have reported that for cancer patients treated with intravenous bisphosphonates the incidence of MRONJ following tooth extraction is expected to range from 1.6-14.8\% with a mean incidence of $7 \%[8,15]$.

This compares to a $1.8 \%$ incidence for oncology patients receiving denosumab and an incidence of MRONJ of $0.5 \%$ for patients taking oral bisphosphonates [8,16-18]. Furthermore, the use of antiangiogenic agents in combination with antiresorptive drugs is known to increase the risk of MRONJ development with an estimate of $16 \%$ of recurrent rates [17].

Studies have reported that dental extractions are the most common cause of MRONJ with figures ranging from $48.5 \%$ to up to $80 \%$ [19]. In a recent study, the trigger of MRONJ was found to be independent of the administration routes, with $61.7 \%$ caused by tooth extraction, $14.8 \%$ by spontaneous onset and $7.4 \%$ by ill-fitting dentures [20]. There is however, limited information about the generating factors for denosumab-related MRONJ.

Many additional factors have been reported in the literature as being associated with accelerated development and/or increased severity of the condition, but for most of these it remains unclear whether or not they are causative factors [21-23]. These include the use of corticosteroids, the presence of concomitant diseases or conditions (e.g., preexisting dental infections, anemia, diabetes-mellitus and immunosuppression or renal failure), poor oral hygiene and smoking [21-24]. The role of genetic factors in MRONJ is also being investigated in order to help to identify patients at increased risk of MRONJ; however, a robust association between MRONJ risk and a specific genetic variant has not yet been identified [25].

After almost 20 years of research there is still lack of consensus regarding the MRONJ diagnostic, preventive and treatment strategies. However, many guidelines have been issued in an attempt to improve the quality of care of patients at risk of MRONJ, Table 1 [1,8,26-36].

An umbrella review on MRONJ was published in 2020 [37]. However, this review presented deficiencies in many aspects, from the quality assessment strategy to the omission of an analysis of the systematic reviews related to epidemiological, diagnostic and preventive strategies studies (non-interventional studies). Hence the aim of this umbrella review is to summarize and assess quality in a comprehensive and complete manner all 
available evidence in published systematic reviews on MRONJ and report the strength and the deficiencies associated with studies included.

Table 1. Chronologic summary of the most common published guidelines/position papers/recommendations.

\begin{tabular}{|c|c|c|}
\hline Guideline/Position Paper/Recommendation & Country & Year \\
\hline $\begin{array}{l}\text { Canadian Consensus of Practice Guidelines for Bisphosphonate Associated Osteonecrosis of } \\
\text { the Jaw [26] }\end{array}$ & Canada & 2008 \\
\hline $\begin{array}{l}\text { Osteonecrosis of the Jaw Complicating Bisphosphonate Treatment for Bone Disease in Multiple } \\
\text { Myeloma: An Overview with Recommendations for Prevention and Treatment [27] }\end{array}$ & Australia & 2009 \\
\hline $\begin{array}{c}\text { The Use of Bisphosphonates in Multiple Myeloma: Recommendations of an Expert Panel on } \\
\text { Behalf of the European Myeloma Network [28] }\end{array}$ & Europe & 2009 \\
\hline $\begin{array}{l}\text { Management of Patients at Risk of Bisphosphonate Osteonecrosis in Maxillofacial Surgery Units } \\
\text { in the UK [29] }\end{array}$ & UK & 2009 \\
\hline $\begin{array}{l}\text { Managing the Care of Patients Receiving Antiresorptive Therapy for Prevention and Treatment of } \\
\text { Osteonecrosis. Executive Summary of Recommendations from the American Dental Association } \\
\text { Council on Scientific Affairs [30] }\end{array}$ & USA & 2011 \\
\hline Guidelines for Supportive Care in Multiple Myeloma 2011 [31] & UK & 2011 \\
\hline Medication-Related Osteonecrosis of the Jaw-2014 Update [8] & USA & 2014 \\
\hline $\begin{array}{l}\text { Diagnosis and Management of Osteonecrosis of the Jaw: A Systematic Review and } \\
\text { International Consensus [32] }\end{array}$ & Canada & 2014 \\
\hline $\begin{array}{l}\text { Medication Related Osteonecrosis of the Jaw: } 2015 \text { Position Statement of the Korean Society for } \\
\text { Bone and Mineral Research and the Korean Association of Oral and Maxillofacial Surgeons [33] }\end{array}$ & Korea & 2015 \\
\hline "Position paper on medication-related osteonecrosis of the jaw (MRONJ)" [34] & Germany & 2016 \\
\hline $\begin{array}{l}\text { Antiresorptive Agent-Related Osteonecrosis of the Jaw: Position Paper } 2017 \text { of the Japanese } \\
\text { Allied Committee on Osteonecrosis of the Jaw [35] }\end{array}$ & Japan & 2016 \\
\hline $\begin{array}{l}\text { Case-Based Review of Osteonecrosis of the Jaw (ONJ) and Application of the International } \\
\text { Recommendations for Management from the International Task Force on ONJ [1] }\end{array}$ & Canada & 2017 \\
\hline Oral Health Management of Patients at Risk of Medication-Related Osteonecrosis of the Jaw [36] & Scotland & 2017 \\
\hline
\end{tabular}

\section{Materials and Methods}

This umbrella review was performed according to the Preferred Reporting Items for Systematic Reviews and Meta-Analyses (PRISMA) guidelines [38].

The protocol of this review was registered in the International Platform of Registered Systematic Review and Meta-analysis Protocols (INPLASY) under the number INPLASY202160061.

The following four databases were explored: PubMed, MEDLINE, EMBASE and CINAHL. A three-stage screening approach was used to ensure precision and safeguard the quality of the search. The screening of titles and abstracts was carried out independently by five authors (RS, JW, OO, EK and OA) to eliminate any irrelevant materials (i.e., reviews, animal studies, non-clinical studies). Disagreements were resolved by discussion until a consensus was reached.

A data screening and abstraction form was used to:

- Verify the study eligibility derived from the inclusion/exclusion criteria. Carry out the methodological quality assessment.

- Extract data on study characteristics and outcomes for the included studies (Figure 1). 


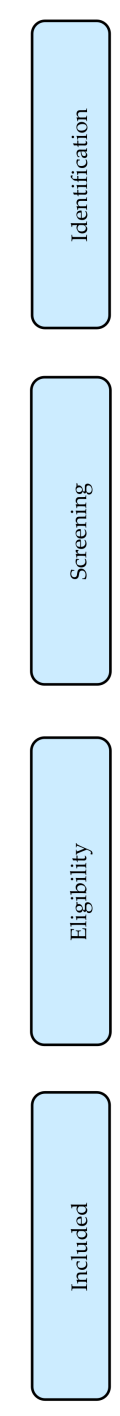

Records identified through database searching PubMed $(n=350)$; EMBASE (280); Medline (249); CINAHL (105)

Additional records identified through other sources (PROSPERO, INPLASY, JBI and OFS $(n=0)$

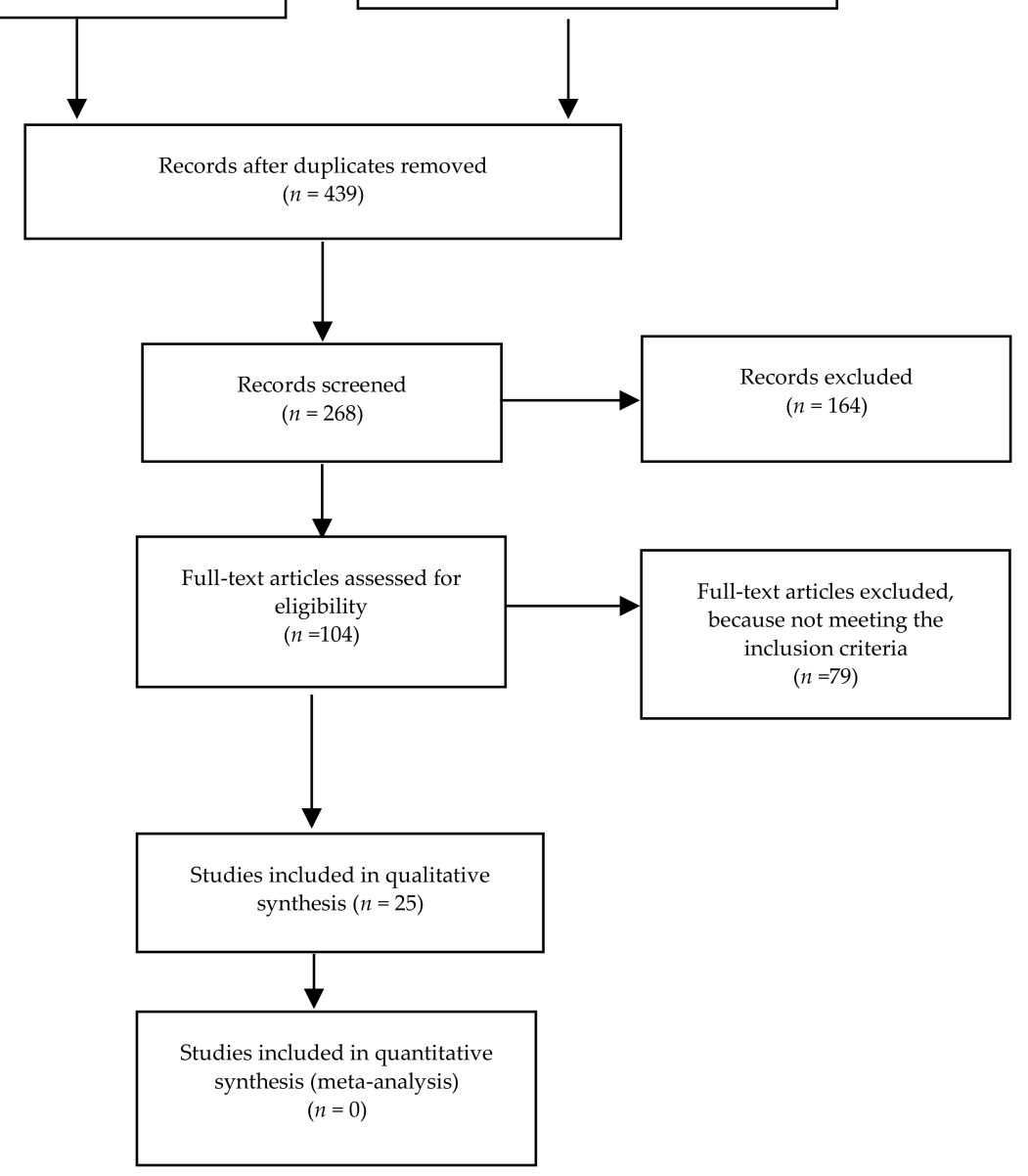

Figure 1. PRISMA study flow diagram.

The authors of any studies eligible for inclusion in the review with insufficient information were contacted directly to provide further information. The inclusion criteria was based on a PICO(S) strategy [39].

Focused question and PICO strategy

What is the current state of evidence related to MRONJ after 18 years of study?

- $\quad$ Population (P): any (no limits of age) patients with MRONJ;

- Interventions (I): any types;

- Comparison (C): any types;

- $\quad$ Outcome (O): state of knowledge based on the type of studies included in the reviews;

- $\quad$ Study (S): systematic review (SR) or meta-analysis (MA).

A search strategy for all databases was developed as follows:

1. Osteonecrosis [MeSH Terms] OR Avascular osteonecrosis of the jaw [MeSH Terms] OR Osteonecrosis of the jaw [MeSH Terms] OR MRONJ [MeSH Terms] OR ONJ [MeSH Terms] OR BONJ [MeSH Terms] OR ARONJ [MeSH Terms] OR BRONJ Patients [MeSH Terms] OR Any patients [MeSH Terms] OR Oncology [MeSH Terms] OR Osteoporosis [MeSH Terms] OR Non-oncologic patients;

2. Systematic review [MeSH Terms] OR Review [MeSH Terms] OR Meta-analysis;

3. 1 and 2 and 3 . 
The search strategy included appropriate changes in the keywords and followed the syntax rules of each database.

\subsection{Criteria for Inclusion in This Review}

\subsubsection{Types of Studies}

The authors of this umbrella review considered both interventional and non-interventional reviews. The search strategy for this study focused on published systematic reviews and/or meta-analysis. Articles were obtained from January 2003 to June 2021. No language restrictions were imposed on the search. Narrative reviews, reviews not following PRISMA guidelines (after 2009), reviews without registration, animal reviews, and those reviews which included patients with a previous history of radiation therapy to the head and/or neck regions were excluded.

\subsubsection{Types of Participants}

The review considered studies involving patients who developed MRONJ after having taken antiresorptive, antiangiogenic and/or any drug therapy associated with osteonecrosis of the jaw. No restriction of age, gender or ethnic origin was applied. There was also no restriction on the minimum number of studies or type of studies included in the systematic reviews and/or meta-analysis.

\subsubsection{Outcomes Measured}

(a) Primary outcome Evaluate the current state of knowledge regarding the medicationrelated osteonecrosis of the jaw as it relates with non-interventional type of studies and interventional type of studies, as well as the trends (number of SR and MA) per year.

(b) Secondary outcome Evaluate factors such as:

- Type of studies included in the reviews;

- Number of patients included in the review;

- Patients' demographic;

- Type of patient groups (Oncology vs. Non-oncology).

\subsubsection{Data Extracted}

All selected papers were carefully read by four independent review authors (RS, OA, JW and JY) and data were extracted using a research report form. The number of included studies, design of the studies, number of patients, results, quality of the evidence and recommendation was recorded. In case of missing information, authors were contacted and given 6 weeks to respond. If the information was not provided, the missing data was recorded as "Not Reported (NR)" in the text and in the tables. A total of 25 systematic reviews were included in this study [40-64].

\subsubsection{Review Quality Assessment Criteria}

Three independent review authors (RS, AA and MDCM) appraised the included studies. The methodological quality of each review was evaluated using the Confidence in Evidence from Reviews of Qualitative (CERQual) research tool recommended by the Grading of Recommendations Assessment, Development and Evaluation Working Group (GRADE). The CERQual evaluation tool enabled the authors to evaluate the included studies, according to four key domains:

(1) The methodological limitations of the individual qualitative studies contributing to a review finding;

(2) The coherence of the review finding;

(3) The adequacy of data supporting a review finding;

(4) The relevance of the data from the primary studies supporting a review finding to the context (perspective or population, phenomenon of interest and/or setting) specified in the review question [65]. 
Any disagreements in risk of bias assessments were referred to the third author of the review team (JY) and subsequently resolved by discussion.

\section{Results}

Initially considered to be potentially eligible for inclusion were 104 studies but after inspection of the full papers, 79 were excluded for not meeting the inclusion criteria for this umbrella review. Results were expressed as descriptive statistics because of the significant heterogeneity in the published data. A total of 25 systematic reviews were therefore included in this study. The included systematic reviews involved a total of 80,840 patients. All the published data described patients evaluated from 2006 to 2021 (Table 2).

Table 2. Systematic reviews included within this analysis. Systematic review (SR); meta-analysis (MA).

\begin{tabular}{|c|c|c|c|}
\hline Authors & Focused Question & Type of Patients & Type of Reviews \\
\hline Aljohani et al. (2017) [40] & $\begin{array}{l}\text { What is the effect of ARDs on MRONJ development in } \\
\text { osteoporosis patients? and what are the risk factors, } \\
\text { demographical and clinical characteristics associated } \\
\text { with MRONJ in this particular group of patients? }\end{array}$ & Osteoporosis & SR \\
\hline Beth-tasdogan et al. (2017) [41] & $\begin{array}{l}\text { What are the effects of different interventions to either } \\
\text { prevent or treat medication-related osteonecrosis of the } \\
\text { jaw compared with each other or compared with no } \\
\text { treatment or an inactive intervention ('placebo')? }\end{array}$ & $\begin{array}{l}\text { Mixed (Oncology \& } \\
\text { Non-Oncology) }\end{array}$ & MA \\
\hline Cabras et al. (2021) [42] & $\begin{array}{l}\text { In populations of patients treated with antiresorptive } \\
\text { agents undergoing tooth extraction, which antibiotic is } \\
\text { more effective in reducing risk of MRONJ, compared } \\
\text { to other antibiotics or placebo? }\end{array}$ & $\begin{array}{l}\text { Mixed (Oncology \& } \\
\text { Non-Oncology) }\end{array}$ & SR \\
\hline Dal Prá et al. (2017) [43] & $\begin{array}{l}\text { Is the C-terminal telopeptide test effective in predicting } \\
\text { the development of bisphosphonate-related } \\
\text { osteonecrosis of the jaw? }\end{array}$ & $\begin{array}{l}\text { Mixed (Oncology \& } \\
\text { Non-Oncology) }\end{array}$ & SR \\
\hline Duarte et al. (2020) [44] & $\begin{array}{l}\text { Can children be affected by bisphosphonate-related } \\
\text { osteonecrosis of the jaw? }\end{array}$ & $\begin{array}{l}\text { Mixed (Oncology \& } \\
\text { Non-Oncology) }\end{array}$ & SR \\
\hline Gelazius et al. (2018) [45] & $\begin{array}{l}\text { Is dental implant placement purposeful for patients } \\
\text { using bisphosphonates? }\end{array}$ & $\begin{array}{l}\text { Mixed (Oncology \& } \\
\text { Non-Oncology) }\end{array}$ & SR \\
\hline Govaerts et al. (2020) [46] & NR & $\begin{array}{l}\text { Mixed (Oncology \& } \\
\text { Non-Oncology) }\end{array}$ & SR \\
\hline Hennedige et al. (2014) [47] & NR & $\begin{array}{l}\text { Osteogenesis } \\
\text { Imperfecta }\end{array}$ & SR \\
\hline Hess et al. (2008) [48] & NR & Non-Oncology & SR \\
\hline Lorenzo pouso et al. (2020) [49] & NR & $\begin{array}{l}\text { Mixed (Oncology \& } \\
\text { Non-Oncology) }\end{array}$ & MA \\
\hline Lorenzo-pouso et al. (2019) [50] & $\begin{array}{l}\text { What are the most effective biomarkers for the risk } \\
\text { assessment of developing BRONJ? }\end{array}$ & $\begin{array}{l}\text { Mixed (Oncology \& } \\
\text { Non-Oncology) }\end{array}$ & SR \\
\hline Madrid \& Sanz (2009) [51] & $\begin{array}{c}\text { In patients on IV or orally administered BPs, what is } \\
\text { the risk of developing BRONJ when dental implants } \\
\text { are placed and what is the impact of BP therapy on } \\
\text { implant outcome? }\end{array}$ & Unclear & SR \\
\hline Mauri et al. (2009) [52] & NR & Oncology & MA \\
\hline McGowan et al. (2018) [53] & NR & $\begin{array}{l}\text { Mixed (Oncology \& } \\
\text { Non-Oncology) }\end{array}$ & SR \\
\hline Migliorati et al. (2010) [54] & NR & Oncology & SR \\
\hline Ottesen et al. (2020) [55] & $\begin{array}{l}\text { Is a high-dose AR drug holiday at the time of tooth } \\
\text { extraction, or other dentoalveolar surgery, necessary to } \\
\text { prevent the development of MRONJ in patients with } \\
\text { cancer? }\end{array}$ & $\begin{array}{l}\text { Mixed (Oncology \& } \\
\text { Non-Oncology) }\end{array}$ & SR \\
\hline Palaska et al. (2009) [56] & NR & $\begin{array}{l}\text { Mixed (Oncology \& } \\
\text { Non-Oncology) }\end{array}$ & SR \\
\hline Querrer et al. (2021) [57] & $\begin{array}{c}\text { Are bisphosphonate-related ONJ and } \\
\text { denosumab-related ONJ any different, regarding } \\
\text { clinical and imaging aspects? }\end{array}$ & $\begin{array}{l}\text { Mixed (Oncology \& } \\
\text { Non-Oncology) }\end{array}$ & SR \\
\hline
\end{tabular}


Table 2. Cont.

\begin{tabular}{|c|c|c|c|}
\hline Authors & Focused Question & Type of Patients & Type of Reviews \\
\hline Rollason et al. (2016) [58] & NR & Oncology & SR \\
\hline Sacco et al. (2021a) [59] & $\begin{array}{l}\text { Is there any sufficient evidence that non-oncological } \\
\text { immunosuppressed patients are at higher risk of } \\
\text { developing ONJ due to antiresorptive drug therapy? }\end{array}$ & Non-Oncology & SR \\
\hline Sacco et al. (2021b) [60] & $\begin{array}{l}\text { Is there any evidence that malignant cells or metastatic } \\
\text { cancer is present within osteonecrosis of the jaws in } \\
\text { patients treated with antiresorptive and/or } \\
\text { antiangiogenic medications? }\end{array}$ & Oncology & SR \\
\hline Sacco et al. (2021c) [61] & $\begin{array}{c}\text { Which is the best available treatment option for } \\
\text { managing antiangiogenic related MRONJ in } \\
\text { oncology patients? }\end{array}$ & Oncology & SR \\
\hline $\begin{array}{c}\text { de Souza Tolentino et al. } \\
\text { (2019) [62] }\end{array}$ & $\begin{array}{l}\text { Does hyperbaric oxygenation have positive effects in } \\
\text { the treatment of medication-related osteonecrosis of } \\
\text { the jaws? Does low-intensity laser therapy have } \\
\text { positive effects in the treatment of medication-related } \\
\text { osteonecrosis of the jaws? Additionally, does } \\
\text { platelet-rich plasma (PRP) have positive effects in the } \\
\text { treatment of medication-related osteonecrosis of } \\
\text { the jaws? }\end{array}$ & $\begin{array}{l}\text { Mixed (Oncology \& } \\
\text { Non-Oncology) }\end{array}$ & MA \\
\hline Woo et al. (2006) [63] & NR & $\begin{array}{l}\text { Mixed (Oncology \& } \\
\text { Non-Oncology) }\end{array}$ & SR \\
\hline Woolley et al. (2021) [64] & $\begin{array}{l}\text { Is there any evidence that orthodontic treatment } \\
\text { induces ONJ or other adverse outcomes inpatients } \\
\text { treated with antiresorptive drug therapy? }\end{array}$ & Non-Oncology & SR \\
\hline
\end{tabular}

The types of systematic review included in this research were: systematic reviews $(n=21 ; 84 \%)$ and meta-analysis reviews $(n=4 ; 16 \%)$. Of these reviews $n=16(64 \%)$ were non-interventional and $n=9(36 \%)$ were interventional. The general characteristics of the studies included are shown in Tables 2 and 3.

Table 3. Type of studies and patients included within respective systematic reviews. Randomized controlled trial (RCT); prospective (PR); retrospective (RE); case series (CS); case report (CR); prospective case-controlled study (P-CCS); retrospective case-controlled study (R-CCS); case-controlled study (CCS); cross-sectional study (CSS); letter to the editor (LE).

\begin{tabular}{|c|c|c|c|}
\hline Authors & $\begin{array}{l}\text { Number and Study Types } \\
\text { Included in the Analysis }\end{array}$ & $\begin{array}{c}\text { Number of Patients } \\
\text { Included in the Research }\end{array}$ & $\begin{array}{l}\text { Type of Drug } \\
\text { Therapy Used }\end{array}$ \\
\hline Aljohani et al. (2017) [40] & 1 PR; 20 RE; 20 CS; 3 CR & 587 & $\begin{array}{c}\text { Antiresorptive (including } \\
\text { denosumab) }\end{array}$ \\
\hline Beth-tasdogan et al. (2017) [41] & $5 \mathrm{RCT}$ & 1218 & $\begin{array}{c}\text { Antiresorptive (including } \\
\text { denosumab) }\end{array}$ \\
\hline Cabras et al. (2021) [42] & 1 RCT; 7 PR; 4 RE; 5 CS & 1888 & $\begin{array}{c}\text { Antiresorptive (including } \\
\text { denosumab) }\end{array}$ \\
\hline Dal Prá et al. (2017) [43] & $8 \mathrm{PR}$ & 1442 & $\begin{array}{c}\text { Antiresorptive (including } \\
\text { denosumab) }\end{array}$ \\
\hline Duarte et al. (2020) [44] & 2 PR; 5 RE & 538 & Bisphosphonate \\
\hline Gelazius et al. (2018) [45] & 1 RCT; 1 PR; 2 RE; 2 CS; 3 CR & 514 & Bisphosphonate \\
\hline Govaerts et al. (2020) [46] & $\begin{array}{c}4 \text { RCT; } 4 \text { P-CCS; } 7 \text { R-CCS; } 7 \\
\text { PR; } 7 \text { RE }\end{array}$ & 1513 & $\begin{array}{l}\text { Antiresorptive (including } \\
\text { denosumab) }\end{array}$ \\
\hline Hennedige et al. (2014) [47] & $4 \mathrm{RE} ; 1 \mathrm{CS}$ & 501 & Bisphosphonate \\
\hline Hess et al. (2008) [48] & 1 RCT; 8 RE; 18 CS; 3 CR & 99 & Bisphosphonate \\
\hline Lorenzo pouso et al. (2020) [49] & 7 CCS; 5 RE & 2995 & Bisphosphonate \\
\hline Lorenzo-pouso et al. (2019) [50] & 6 P-CCS; 1 LE & 2623 & Bisphosphonate \\
\hline
\end{tabular}


Table 3. Cont.

\begin{tabular}{|c|c|c|c|}
\hline Authors & $\begin{array}{l}\text { Number and Study Types } \\
\text { Included in the Analysis }\end{array}$ & $\begin{array}{l}\text { Number of Patients } \\
\text { Included in the Research }\end{array}$ & $\begin{array}{l}\text { Type of Drug } \\
\text { Therapy Used }\end{array}$ \\
\hline Madrid \& Sanz (2009) [51] & 1 P-CCS; 3 RE & 1561 & Bisphosphonate \\
\hline Mauri et al. (2009) [52] & $15 \mathrm{RCT}$ & 10,707 & Bisphosphonate \\
\hline McGowan et al. (2018) [53] & Unclear & 4106 & $\begin{array}{l}\text { Antiresorptive (including } \\
\text { denosumab) }\end{array}$ \\
\hline Migliorati et al. (2010) [54] & Unclear & 39,124 & Bisphosphonate \\
\hline Ottesen et al. (2020) [55] & 3 PR; 10 RE; 1 CS & 2100 & $\begin{array}{c}\text { Antiresorptive (including } \\
\text { denosumab) }\end{array}$ \\
\hline Palaska et al. (2009) [56] & $72 \mathrm{CS} ; 33 \mathrm{CR}$ & 656 & Bisphosphonate \\
\hline Querrer et al. (2021) [57] & 2 RCT; 5 CSS & 7755 & Antiresorptive \\
\hline Rollason et al. (2016) [58] & $1 \mathrm{RCT}$ & 49 & Bisphosphonate \\
\hline Sacco et al. (2021a) [59] & $9 \mathrm{RE} ; 8 \mathrm{CS} ; 10 \mathrm{CR}$ & 206 & $\begin{array}{l}\text { Bisphosphonate and } \\
\text { anti-TNF inhibitors }\end{array}$ \\
\hline Sacco et al. (2021b) [60] & 3 PR; 2 RE; 2 CS; 6 CR & 37 & Bisphosphonate \\
\hline Sacco et al. (2021c) [61] & 1 RCT; 7 CS; 20 CR & 36 & Antiangiogenic \\
\hline $\begin{array}{l}\text { de Souza Tolentino et al. } \\
\text { (2019) [62] }\end{array}$ & 1 RCT; 5 PR; 4 RE; 3 CS & 188 & Antiresorptive \\
\hline Woo et al. 2006 [63] & Unclear & 368 & Bisphosphonate \\
\hline Woolley et al. (2021) [64] & $1 \mathrm{RE} ; 1 \mathrm{CS} ; 5 \mathrm{CR}$ & 29 & Bisphosphonate \\
\hline
\end{tabular}

The most common design of review was a non-interventional epidemiological design ( $n=13 ; 52 \%)$ (incidence, frequency and associated risks of MRONJ) followed by an interventional design $n=6(24 \%)$.

The most common drug type therapy investigated in the reviews included in this study were bisphosphonates $60 \%$, while antiangiogenic drug therapy was investigated in $4 \%$ of the studies.

The most frequent type of articles included in the reviews included in this study were case series $(n=140 ; 20.5 \%)$ followed by retrospective cohort studies $(n=84 ; 12.3 \%)$ and case report $(n=83 ; 12.2 \%)$. Regarding their study design, 277 articles $(40.5 \%)$ were unable to be categorized.

The reviews included in the study predominantly analyzed the evidence related to MRONJ in both oncology and non-oncologic patients $(n=14 ; 56 \%)$. A small number considered only oncologic patients $(n=5 ; 20 \%$ ) (Table 3 and Figure 2 ).

A number of reviews included in this study did not report a formal risk of bias quality analysis $(n=5 ; 20 \%)$, likely due to the year of article publications (antecedent to the PRISMA checklist guidance methodology).

All the results presented in the reviews included in this study were highlighted as having a lack of evidence or providing any conclusive suggestions (Table 4). 


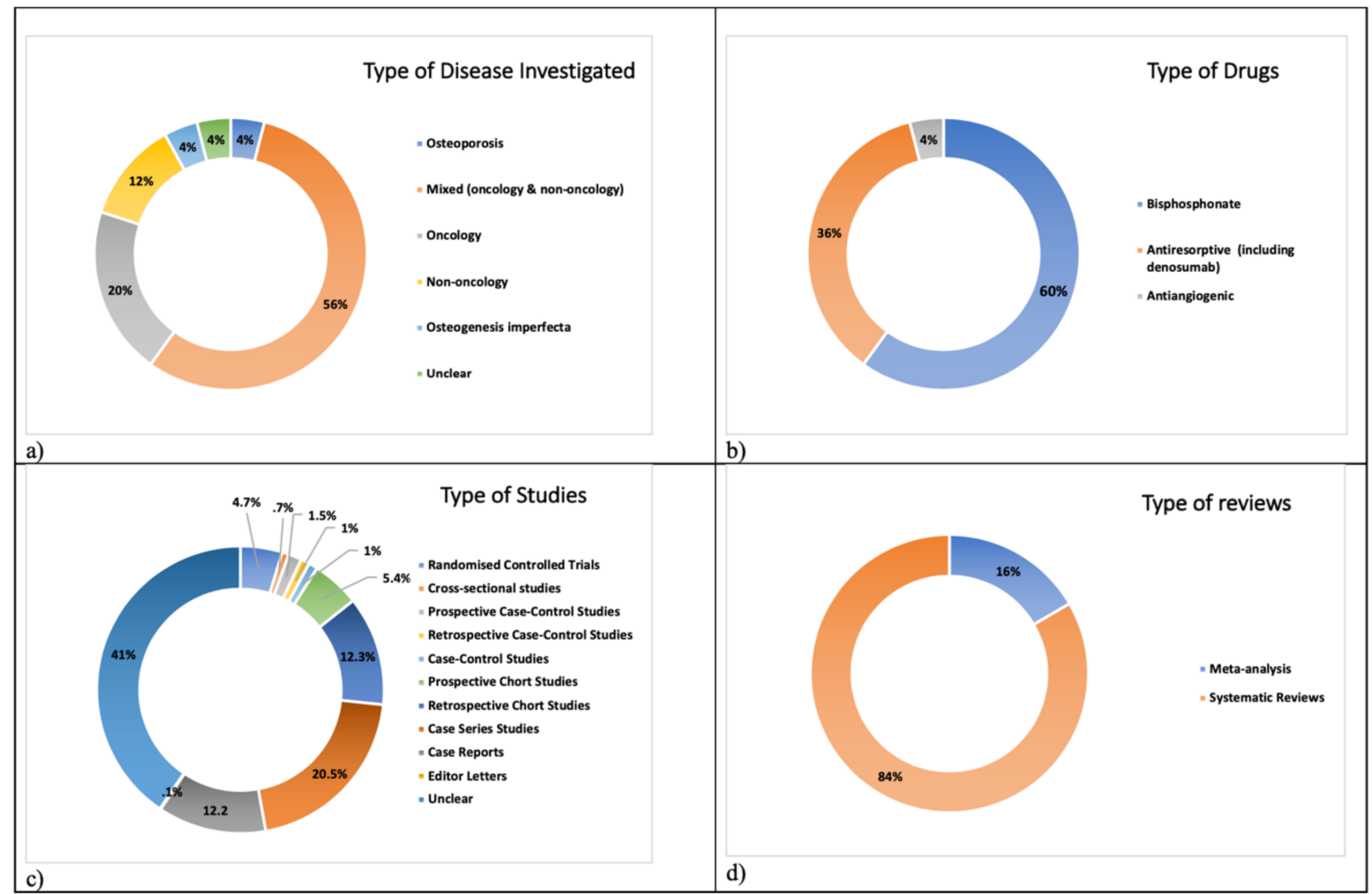

Figure 2. Overview of the study characteristics: (a) type of the disease analyzed in the reviews included in the study; (b) type of drugs analyzed in the reviews included in the study; (c) type of studies analyzed in the reviews included in the study; (d) type of reviews included in the study.

Table 4. Results from included reviews.

\section{Non-Interventional Reviews}

\section{Author}

Aljohani et al. (2017) [40]

Cabras et al. (2021) [42]

Dal Prá et al. (2017) [43]

Duarte et al. (2020) [44]
The mean age of MRONJ osteoporosis patients in our study was $69.7 \pm 5.2$ years. The mandible was the most common site $(394,70.6 \%)$, followed by maxilla (152 case, $27.2 \%$ ) and then in both of them (only 12 cases, $2.2 \%$ ). The ratio of mandible to maxilla and both jaws involvement was 2.4:1. There was variability in the duration of BPs therapy, which ranged from 2 weeks to 93 months, with a mean duration of $51.9 \pm 18$ months. Extraction was the most frequently reported preceding event (244 patients, $48.5 \%$ ).

The data acquired from the moderate/high risk of bias studies suggested that 2-3 g of amoxicillin daily, either alone or in combination with clavulanate, for 6-7 days is the most commonly used antibiotic treatment to minimize risk of MRONJ in patients requiring a dental extraction, which could provide reduction of MRONJ risk.

All eight of the selected studies found that CTX levels were not predictive of the development of BRONJ. In conclusion, this systematic review indicates that the CTX test has no predictive value in determining the risk of osteonecrosis in patients taking bisphosphonates.

Although no cases of osteonecrosis were identified, all studies had weaknesses such as a limited sample size or the absence of risk factors for the development of osteonecrosis. However, it is believed that patients with secondary osteoporosis who use bisphosphonates continuously should be followed up during adulthood, since bone turnover decreases over the years. 
Table 4. Cont.

\begin{tabular}{ccc}
\hline & Non-Interventional Reviews & \\
\hline Author & Result \\
\hline
\end{tabular}

Hennedige et al. (2014) [47]

Hess et al. (2008) [48]
Currently, osteogenesis imperfecta patients are treated as high-risk candidates for developing osteonecrosis of the jaw after dental extractions. However, there is no evidence to support hypothesis of causal relationship between bisphosphonates and osteonecrosis of the jaw in children and adolescents with osteogenesis imperfecta.

Common risk factors, which were associated with $88.9 \%$ of all non-cancer cases of osteonecrosis of the jaw among bisphosphonate users were:

- Dental procedures were most common among osteoporosis patients (92.5\%) and less common among Paget's disease patients (67\%) before onset of osteonecrosis of the jaw. A longer duration of bisphosphonate use in osteoporotic patients (93.5\% more than 1 year of use) compared with Paget's disease (60\% more than 1 year of use) or other patients (33.3\% more than 1 year of use).

- Underlying medical conditions (81.3\%) and reported concomitant use of medications that affect bone turnover $(70.9 \%)$. The most common concomitant medical conditions included hypertension, hyperlipidemia, and hypercholesterolemia (22.6\%).

- Patient taking medications that affect bone turnover, the most commonly used medication affecting bone metabolism included steroids (52.2\%).

Lorenzo pouso et al. (2020) [49]

MRONJ appears to be associated with an increase in prevalence of periodontal disease. However, the lack of scientific evidence in this matter does not allow clear conclusions to be drawn.

A total of seven biomarkers were identified and classified into three groups: bone turnover, angiogenesis and endocrine markers. Conflicting results were found in relation to most biomarkers, which suggest that no useful markers are currently available to evaluate BRONJ risk.

Lorenzo-pouso et al. (2019) [50]

Overall, osteonecrosis of the jaw was a rare event, occurring in $13(0.24 \%)$ of the 5312 patients receiving bisphosphonates. Treatment with zoledronic acid was significantly associated with the occurrence of osteonecrosis of the jaw (OR $=3.23,95 \%$ $\mathrm{CI}=1.7-8)$ compared with no use.

A total of 4106 patients with MRONJ were identified, 39 different systemic diseases were implicated, and 14 medical and 11 dental risk factors were reported, although no statistical analysis of the significance of each of these factors was possible. However, the most reported dental risk factor was tooth extraction $(45 \%)$, followed by periodontal disease $(10 \%)$.

- The prevalence results observed were different depending on the type of study design. The overall weighted prevalence of BON included a sample of 39,124 patients with a mean weighted prevalence of $6.1 \%$. The weighted prevalence was $13.3 \%$ for studies with documented follow-up. The overall prevalence for patients using zoledronic acid only was $8.6 \%$, for pamidronate $7.3 \%$, and $21 \%$ for patients who used both.

Migliorati et al. (2010) [54]

- There were no studies evaluating the economic impact of BON.

- The poor reporting of outcomes of treatment did not allow us to determine success or failure rates of the treatment strategies.

- The weighted mean time to event was estimated to be 21.9 months (1.8 years), with a median minimum time of 10 months.

- $\quad$ The weighted mean time to event for pamidronate was found to be 33.8 months

Palaska et al. (2009) [56]
( 2.8 years), whereas the median value for the minimum duration was estimated to be 18 months.

- The majority of the oral BP users were treated for osteoporosis, weighted mean time to event to be 4.6 years, whereas the median minimum time to event was 3 years. 
Table 4. Cont.

\begin{tabular}{cl}
\hline \multicolumn{1}{c}{ Author } & \multicolumn{1}{c}{ Non-Interventional Reviews } \\
\hline Querrer et al. (2021) [57] & $\begin{array}{l}\text { An increase in bone sequestra, cortical bone lysis, and bone density was observed in } \\
\text { bisphosphonate-related ONJ, while larger bone sequestra, more frequent periosteal } \\
\text { reactions, and mandibular canal enhancement were noted in denosumab-related ONJ. }\end{array}$ \\
\hline Sacco et al. (2021a) [59] & $\begin{array}{l}\text { The data reviewed have confirmed that an invasive procedure is the most common } \\
\text { trigger of MRONJ with relatively high frequency of postoperative complications or } \\
\text { recurrence following management. However, due to low-quality research available in } \\
\text { the literature, it is difficult to ascertain quantitatively the susceptibility of } \\
\text { immunosuppressed patients in the development of MRONJ in non-oncology patients. }\end{array}$ \\
\hline Sacco et al. (2021b) [60] & $\begin{array}{l}\text { Based on the limited data available in literature, it is plausible that not histologically } \\
\text { analyzing all ONJ specimens could result in a small amount of undiagnosed and } \\
\text { untreated malignant diseases (4.64\% based on large cohort studies). }\end{array}$ \\
\hline $\begin{array}{l}\text { Lack of evidence whether orthodontic treatment can precipitate MRONJ. Moreover, } \\
\text { antiresorptive drug therapy has been associated with a sub-optimal treatment } \\
\text { outcome. The review reported adverse outcomes including: difficulty achieving root } \\
\text { parallelism, difficulty achieving complete space closure, exaggerated mobility } \\
\text { post-debond, increased duration of orthodontic treatment beyond expected } \\
\text { completion, sclerotic alveolar bone changes seen on post-op radiographic images, an } \\
\text { increased amount of root resorption and one case of ONJ. }\end{array}$
\end{tabular}

\section{Interventional Reviews}

\section{Author}

Beth-tasdogan et al. (2017) [41]

Gelazius et al. (2018) [45]

Govaerts et al. (2020) [46]

Madrid \& Sanz (2009) [51]

Ottesen et al. (2020) [55]

Rollason et al. (2016) [58]

Sacco et al. (2021c) [61]

\section{Result}

Available evidence is insufficient to either claim or refute a benefit for hyperbaric oxygen therapy as an adjunct to conventional therapy. There is also insufficient evidence to draw conclusions about autofluorescence-guided versus tetracycline fluorescence-guided bone surgery. Moreover, there is insufficient evidence to conclude that the use of the other interventions investigated would reduce the risk of MRONJ or would improve healing of MRONJ.

Patients with intraoral therapy appeared to have a better implant survival ( 5 implants failed out of 423 ) rate at $98.8 \%$ vs. patients treated intravenously ( 6 implants failed out of 68 ) at $91 \%$.

Laser ablation had a success of $60-95 \%$ for complete healing. The controlled trials of leukocyte- and platelet-rich fibrin (LPRF) showed 60-100\% success for the same outcome. Fluorescence-guided surgery had a complete healing percentage of $85-90 \%$.

From the analysis yield in this study, the placement of an implant may be considered a safe procedure in patients taking oral BPs for 5 years with regard to the occurrence of BRONJ since in these studies no BRONJ has been reported.

There is no evidence for using a drug holiday, but it is also clear that caused by a limited numbers of eligible patients, and a great variation in between these patients, high-level evidence for using an AR drug holiday is almost impossible to obtain this data.

There is a lack of evidence from randomized controlled trials to guide treatment of bisphosphonate-related osteonecrosis of the jaw (BRONJ).

The data reviewed confirmed that an invasive procedure is the most common trigger of MRONJ. The overall MRONJ disease recurrence was identified in $n=6(16.6 \%)$ cases. Two $(n=2)$ recurrences were observed in the conservative treatment group, $n=3$ recurrences were recognized in the conservative and antibiotics treatment group of patients and $n=1$ was observed in the surgical treatment group. However, due to the low quality of available research in literature, it is difficult to draw a definitive conclusion on the validity of the presented treatment to manage patients affected by MRONJ associated with angiogenic therapy. 
Table 4. Cont.

\begin{tabular}{|c|c|}
\hline \multicolumn{2}{|r|}{ Interventional Reviews } \\
\hline Author & Result \\
\hline & $\begin{array}{l}\text { Adjuvant therapies hyperbaric oxygen (HBO), low-intensity laser (LIL), and } \\
\text { platelet-rich plasma (PRP) have positive effects on MRONJ treatment, being safe and } \\
\text { well-tolerated. }\end{array}$ \\
\hline de Souza Tolentino et al. (2019) [62] & $\begin{array}{l}\text { - There was improvement in } 75.6 \% \text { of the patients submitted to HBO. For LIL, } \\
64.2 \% \text { of the patients/sites improved the symptoms and } 39.8 \% \text { healed completely. } \\
\text { - For PRP, } 17.3 \% \text { of the } 81 \text { patients treated, had significantly improved the } \\
\text { symptoms and } 80.2 \% \text { completely healed. }\end{array}$ \\
\hline Woo et al. (2006) [63] & $\begin{array}{l}\text { Over suppression of bone turnover is probably the primary mechanism for the } \\
\text { development of this condition, although there may be contributing comorbid factors. } \\
\text { All sites of potential jaw infection should be eliminated before bisphosphonate therapy } \\
\text { is initiated in these patients to reduce the necessity of subsequent dentoalveolar } \\
\text { surgery. Conservative debridement of necrotic bone, pain control, infection } \\
\text { management, use of antimicrobial oral rinses, and withdrawal of bisphosphonates are } \\
\text { preferable to aggressive surgical measures for treating this condition. }\end{array}$ \\
\hline
\end{tabular}

\section{Review Quality Assessment}

The assessment of each CERQual component was based on judgements by the review authors and these judgements were described and detailed in CERQual Qualitative Evidence Profile (Table 5).

- Methodological limitations: The extent to which there are problems in the design or conduct of the primary studies that contributed evidence to a review finding.

- Relevance: The extent to which the body of evidence from the primary studies supporting a review finding is applicable to the context (perspective or population, phenomenon of interest, setting) specified in the review question.

- Coherence: The extent to which the review finding is well grounded in data from the contributing primary studies and provides a convincing explanation for the patterns found in these data.

- Adequacy of data: An overall determination of the degree of richness and quantity of data supporting a review finding.

** The CERQual approach-Definitions of levels of confidence in a review finding

- High confidence: It is highly likely that the review finding is a reasonable representation of the phenomenon of interest.

- Moderate confidence: It is likely that the review finding is a reasonable representation of the phenomenon of interest.

- Low confidence: It is possible that the review finding is a reasonable representation of the phenomenon of interest.

- Very low confidence: It is not clear whether the review finding is a reasonable representation of the phenomenon of interest. 
Table 5. Quality assessment.

\begin{tabular}{|c|c|c|c|c|c|c|c|}
\hline $\begin{array}{l}\text { Systematic Review } \\
\text { Category }\end{array}$ & Study/Studies & $\begin{array}{l}\text { Assessment of } \\
\text { Methodological } \\
\text { Limitations * }\end{array}$ & $\begin{array}{l}\text { Assessment of } \\
\text { Relevance * }\end{array}$ & $\begin{array}{l}\text { Assessment of } \\
\text { Coherence * }\end{array}$ & $\begin{array}{l}\text { Assessment of } \\
\text { Adequacy * }\end{array}$ & $\begin{array}{l}\text { Overall CERQual } \\
\text { Assessment of } \\
\text { Confidence } * *\end{array}$ & Explanation of Judgement \\
\hline $\begin{array}{l}\text { Epidemiological type } \\
\text { of reviews } \\
\text { (non-interventional) }\end{array}$ & $\begin{array}{c}\text { Aljohani et al. (2017) [40]; } \\
\text { Duarte et al. (2020) [44]; } \\
\text { Hennedige et al. (2014) [47]; } \\
\text { Hess et al. (2008) [48]; } \\
\text { Lorenzo pouso et al. (2020) [49]; } \\
\text { Mauri et al. (2009) [52]; } \\
\text { McGowan et al. (2018) [53]; } \\
\text { Migliorati et al. (2010) [54]; } \\
\text { Palaska et al. (2009) [56]; } \\
\text { Sacco et al. (2021a) [59]; } \\
\text { Sacco et al. (2021b) [60]; } \\
\text { de Souza Tolentino et al. } \\
\text { (2019) [62]; } \\
\text { Woolley et al. (2021) [64] }\end{array}$ & $\begin{array}{l}\text { Serious concerns regarding } \\
\text { methodological limitations } \\
\text { in four studies and } \\
\text { moderate concerns } \\
\text { regarding methodological } \\
\text { limitations in eight studies }\end{array}$ & $\begin{array}{l}\text { Minor concerns } \\
\text { regarding relevance } \\
\text { in all studies }\end{array}$ & $\begin{array}{l}\text { Minor concerns } \\
\text { regarding } \\
\text { coherence in all } \\
\text { studies }\end{array}$ & $\begin{array}{l}\text { Serious Concerns } \\
\text { regarding adequacy } \\
\text { in all studies }\end{array}$ & Very low confidence & $\begin{array}{l}\text { This finding was graded as: } \\
\text { minor concerns for } \\
\text { relevance and coherence in } \\
\text { all studies, moderate } \\
\text { concerns regarding } \\
\text { methodological limitations } \\
\text { in eight studies and serious } \\
\text { concerns regarding } \\
\text { methodological limitations } \\
\text { four studies and adequacy } \\
\text { of data results in all studies }\end{array}$ \\
\hline $\begin{array}{l}\text { Management type of } \\
\text { reviews } \\
\text { (interventional) }\end{array}$ & $\begin{array}{l}\text { Beth-tasdogan et al. (2017) [41]; } \\
\text { Govaerts et al. (2020) [46]; } \\
\text { Rollason et al. (2016) [58]; } \\
\text { Sacco et al. (2021c) [61]; } \\
\text { Woo et al. 2006 [63] }\end{array}$ & $\begin{array}{l}\text { Serious concerns regarding } \\
\text { methodological limitations } \\
\text { in one study, moderate } \\
\text { concerns regarding } \\
\text { methodological limitations } \\
\text { in three studies and minor } \\
\text { concerns regarding } \\
\text { methodological limitations } \\
\text { in two studies and }\end{array}$ & $\begin{array}{l}\text { Minor concerns } \\
\text { regarding relevance } \\
\text { in all studies }\end{array}$ & $\begin{array}{l}\text { Minor concerns } \\
\text { regarding } \\
\text { coherence in all } \\
\text { studies }\end{array}$ & $\begin{array}{l}\text { Serious concerns } \\
\text { regarding adequacy } \\
\text { in all studies }\end{array}$ & Very low confidence & $\begin{array}{l}\text { This finding was graded as: } \\
\text { minor concerns for } \\
\text { relevance and coherence, } \\
\text { moderate concerns } \\
\text { regarding methodological } \\
\text { limitations in three studies } \\
\text { and serious concerns } \\
\text { regarding methodological } \\
\text { limitations (one study) and } \\
\text { adequacy of data results }\end{array}$ \\
\hline $\begin{array}{l}\text { Predicting biomarkers } \\
\text { type of reviews } \\
\text { (non-interventional) }\end{array}$ & $\begin{array}{l}\text { Dal Prá et al. (2017) [43]; } \\
\text { Lorenzo-pouso et al. (2019) [50] }\end{array}$ & $\begin{array}{l}\text { Serious concerns regarding } \\
\text { methodological limitations } \\
\text { in one study and moderate } \\
\text { concerns regarding } \\
\text { methodological limitations } \\
\text { in one study }\end{array}$ & $\begin{array}{l}\text { Minor concerns } \\
\text { about relevance }\end{array}$ & $\begin{array}{l}\text { Minor concerns } \\
\text { about coherence in } \\
\text { both studies }\end{array}$ & $\begin{array}{l}\text { Serious concerns } \\
\text { regarding adequacy } \\
\text { in both studies }\end{array}$ & Very low confidence & $\begin{array}{l}\text { This finding was graded as: } \\
\text { minor concerns for } \\
\text { relevance and coherence, } \\
\text { moderate concerns } \\
\text { regarding methodological } \\
\text { limitations and serious } \\
\text { concerns regarding } \\
\text { methodological limitations } \\
\text { (one study) and adequacy of } \\
\text { data results }\end{array}$ \\
\hline
\end{tabular}


Table 5. Cont

\begin{tabular}{|c|c|c|c|c|c|c|c|}
\hline $\begin{array}{l}\text { Systematic Review } \\
\text { Category }\end{array}$ & Study/Studies & $\begin{array}{l}\text { Assessment of } \\
\text { Methodological } \\
\text { Limitations * }\end{array}$ & $\begin{array}{l}\text { Assessment of } \\
\text { Relevance * }\end{array}$ & $\begin{array}{l}\text { Assessment of } \\
\text { Coherence * }\end{array}$ & $\begin{array}{l}\text { Assessment of } \\
\text { Adequacy * }\end{array}$ & $\begin{array}{l}\text { Overall CERQual } \\
\text { Assessment of } \\
\text { Confidence } \\
* *\end{array}$ & Explanation of Judgement \\
\hline $\begin{array}{l}\text { Dental rehabilitation } \\
\text { (interventional) }\end{array}$ & $\begin{array}{l}\text { Gelazius et al. (2018) [45]; } \\
\text { Madrid \& Sanz (2009) [51] }\end{array}$ & $\begin{array}{l}\text { Serious concerns regarding } \\
\text { methodological limitations } \\
\text { in one study and moderate } \\
\text { concerns regarding } \\
\text { methodological limitations } \\
\text { in one study }\end{array}$ & $\begin{array}{l}\text { Minor concerns } \\
\text { regarding relevance }\end{array}$ & $\begin{array}{l}\text { Moderate concerns } \\
\text { regarding } \\
\text { coherence in both } \\
\text { studies }\end{array}$ & $\begin{array}{l}\text { Serious concerns } \\
\text { regarding adequacy } \\
\text { in both studies }\end{array}$ & Very low confidence & $\begin{array}{l}\text { This finding was graded as: } \\
\text { minor concerns for } \\
\text { relevance, moderate } \\
\text { concerns regarding } \\
\text { methodological limitations } \\
\text { and coherence, and serious } \\
\text { concerns regarding } \\
\text { adequacy of data results }\end{array}$ \\
\hline $\begin{array}{l}\text { Preventive strategy } \\
\text { type of review } \\
\text { (interventional) }\end{array}$ & Ottesen et al. (2020) [55] & $\begin{array}{l}\text { Moderate concerns } \\
\text { regarding methodological } \\
\text { limitations }\end{array}$ & $\begin{array}{l}\text { Minor concerns } \\
\text { regarding relevance }\end{array}$ & $\begin{array}{l}\text { Minor concerns } \\
\text { regarding } \\
\text { coherence }\end{array}$ & $\begin{array}{l}\text { Serious concerns } \\
\text { regarding adequacy }\end{array}$ & Very low confidence & $\begin{array}{l}\text { This finding was graded as: } \\
\text { minor concerns for } \\
\text { relevance and coherence, } \\
\text { moderate concerns } \\
\text { regarding methodological } \\
\text { limitations and serious } \\
\text { concerns regarding } \\
\text { adequacy of data results }\end{array}$ \\
\hline $\begin{array}{l}\text { Preventive strategy } \\
\text { type of review } \\
\text { (non-interventional) }\end{array}$ & Cabras et al. (2021) [42] & $\begin{array}{l}\text { Serious concerns regarding } \\
\text { methodological }\end{array}$ & $\begin{array}{l}\text { Minor concerns } \\
\text { regarding relevance }\end{array}$ & $\begin{array}{l}\text { Minor concerns } \\
\text { regarding } \\
\text { coherence }\end{array}$ & $\begin{array}{l}\text { Serious concerns } \\
\text { regarding } \\
\text { Adequacy }\end{array}$ & Very low confidence & $\begin{array}{l}\text { This finding was graded as: } \\
\text { minor concerns for } \\
\text { relevance, moderate } \\
\text { concerns regarding } \\
\text { methodological limitations } \\
\text { and coherence, and serious } \\
\text { concerns regarding } \\
\text { adequacy of data results }\end{array}$ \\
\hline $\begin{array}{c}\text { Diagnostic type of } \\
\text { review } \\
\text { (non-interventional) }\end{array}$ & Querrer et al. (2021) [56] & $\begin{array}{c}\text { Moderate concerns } \\
\text { regarding methodological } \\
\text { limitations }\end{array}$ & $\begin{array}{l}\text { Minor concerns } \\
\text { regarding relevance }\end{array}$ & $\begin{array}{l}\text { Minor concerns } \\
\text { regarding } \\
\text { coherence }\end{array}$ & $\begin{array}{l}\text { Serious concerns } \\
\text { regarding adequacy }\end{array}$ & Very low confidence & $\begin{array}{l}\text { This finding was graded as: } \\
\text { minor concerns for } \\
\text { relevance and coherence, } \\
\text { moderate concerns } \\
\text { regarding methodological } \\
\text { limitations and serious } \\
\text { concerns regarding } \\
\text { adequacy of data results }\end{array}$ \\
\hline
\end{tabular}

* Components of the CERQual approach. 
In summary the authors found that:

- There were minor concerns with respect to the relevance and coherence of the epidemiological type of reviews in all studies. Moderate concerns were noted regarding the methodological limitations in eight studies and serious concerns were highlighted for similar limitations in four studies. Serious concerns were also noted for the adequacy of data of their results in all of the included studies. Due to the high number of serious concerns, particularly regarding methodology and result data, the overall assessment was assessed as very low confidence (lack of clarity whether the review finding is a reasonable representation of the phenomenon of interest).

- Minor concerns were highlighted with respect to the relevance and coherence of management types of reviews. Moderate concerns were raised regarding methodological limitations in three studies and serious concerns in methodological limitations in one study. Serious concerns were raised for one study regarding the adequacy of data in the results. Due to these concerns, the overall assessment regarding the management type was graded as very low confidence (lack of clarity whether the review finding is a reasonable representation of the phenomenon of interest).

- With respect to predicting markers, the reviews were graded as having minor concerns for relevance and coherence, moderate concerns regarding methodological limitations and serious concerns regarding methodological limitations and adequacy of the result data. Due to these concerns, the overall assessment regarding predicting markers was rated as having very low confidence (lack of clarity whether the review finding is a reasonable representation of the phenomenon of interest).

- Relating to dental rehabilitation, reviews were graded with minor concerns for relevance, moderate concerns regarding methodological limitations and coherence, and serious concerns regarding adequacy of result data. This domain again was graded as having very low confidence (lack of clarity whether the review finding is a reasonable representation of the phenomenon of interest).

- Regarding preventive strategy, reviews demonstrated minor concerns for relevance and coherence, moderate concerns regarding methodological limitations and serious concerns regarding adequacy of data results. The overall assessment for preventative strategy was rated as very low confidence (lack of clarity whether the review finding is a reasonable representation of the phenomenon of interest).

- Finally, when assessing the diagnostic investigations within the reviews, this review identified minor concerns regarding relevance and coherence, moderate concerns regarding methodological limitations and serious concerns regarding adequacy of the data results. Therefore, with regard to the overall assessment, this domain was graded as very low confidence (lack of clarity whether the reviews found a reasonable representation of the phenomenon of interest).

\section{Discussion}

Medication-related osteonecrosis of the jaw (MRONJ) is a rare but disabling disease $[1,8,66]$. Currently, the aetiopathogenesis of MRONJ has not been well explained despite a large number of patients suffering from this severe adverse event [8].

At present there are three key theories proposed for the pathogenesis of MRONJ; bone turnover suppression, cellular toxicity and infection. Whereas circumstantial studies underpin the hypothesis that antiresorptive drugs reduce bone formation and promote necrosis, physiological and radiological research suggest different findings. The hypotheses of drug-related cellular toxicity affecting epithelial cells and macrophages causing limited immune defence as a result of impaired functions has been purported by many ex vivo and in vivo studies. Infection is believed to be an important contributing factor to the disease as it can encourage extreme bone resorption. Whether it is the generating factor or the result of the disease process still remains unclear [67]. Additional studies are necessary to confirm the exact pathological process of anti-angiogenic drugs as their drug actions are different from bisphosphonates and denosumab. 
Despite the great collaborative effort in the past decades in investigating MRONJ, there are many unanswered questions and a lack of a common agreement among researchers and investigators.

Although there are many systematic reviews on the subject, there is still no unanimous consensus on many aspects of MRONJ from preventive strategy, to the management of the disease [41]. Despite the limited evidence available, many countries have established guidelines in the attempt to improve the care of these vulnerable patients.

Using the Oxford Centre for Evidence-Based Medicine (1a, 2a and 3a), the present umbrella review looked at the current highest available evidence published in the last 20 years on drug-induced ONJ in the attempt to highlight the current state of the quality of research [68].

Among the systematic reviews and meta-analysis included in this study, we noticed a very broad inclusion criteria adopted by authors of the many reviews. This is evident from the study numbers included in the reviews, which varied from 1 article [58] to 219 articles [53]. Except for the few meta-analyses included in this review, most of the included articles were often weak, low ranked and demonstrated a high risk of bias [41,52]. These methodological inadequacies have undoubtedly increased the risk of inconsistency of the general guidelines worldwide, resulting in lack of effectiveness in handling patients at risk or affected by MRONJ.

The authors have discovered that the majority of the reviews feature predominantly case reports, case series, and observational studies. For this reason, the findings of these reviews should be interpreted cautiously [48,56,59-61,64]. This review also revealed that a large number of systematic reviews in the literature (excluded in this article) do not follow the recognized PRISMA checklist guidance, which inevitably increases the chances of methodological errors and reporting bias.

In the future, systematic reviews or meta-analysis should outline a clear protocol before conducting the study; with the foresight that these pieces of research are often fundamental tools used to implement clinical practice in the form of guidelines. Unusually, systematic reviews have clear protocols. However, we have noticed that many of the 24 included reviews did not perform a comprehensive search for studies, report funding for included studies or conduct a satisfactory risk bias analysis $[56,63]$. These shortcomings are likely to have increased the issues surrounding the adequacy of their results, resulting in low strength of evidence in the published conclusions.

Despite the large number of systematic reviews on MRONJ, there is still discordant thought without a unanimous consensus on many aspects of MRONJ, from preventive strategy to the management of the disease.

In the future, it is essential to conduct studies with improved quality, including randomized-controlled trials that support evidence-based treatment protocols. In general, the authors advocate that the following rules should be applied for future MRONJ research studies:

- Sample size calculation should be established and employed for all the RCTs. Large RCTs should be carried out and described in sufficient detail to allow precise assessment, management and/or epidemiological findings.

- Risk stratification should be applied for any clinical studies in order to minimize the effect modification and/or confounding factors that could potentially affect the final result/s.

- Common, quantifiable and clinically relevant endpoints (time to complete wound healing, pain, specific investigations, treatment acceptability and participant satisfaction) should be described in sufficient detail particularly in patients undergoing to any type of intervention including preventive strategies.

- An adequate follow-up period is essential if MRONJ treatment or preventive strategy is studied in order to evaluate the long-term effects on this group of patients.

- A predictable special investigation, such as CT, CBCT or MRI should be used for any of the observational and interventional studies at diagnosis and during the follow-up. 


\section{Conclusions}

Through this umbrella review, it has become clear that there is limited high strength evidence to support many of the current recommendations surrounding medication-related osteonecrosis of the jaw. The low quality systematic reviews and meta-analyses highlighted by this study show no insightful therapeutic recommendations, preventive strategies, risk reduction or standards that can be applied for this debilitating disease. A number of higher quality clinical studies are necessary to make evidence-based decisions on MRONJ therapies.

Author Contributions: R.S. conceived the presented systematic review idea and the design of the study; R.S., C.F.d.A.B.M., J.W., O.A., V.M., E.K., A.A., O.O. and J.Y. contributed to the acquisition, analysis, and the interpretation of data for the work; R.S., M.D.C.-M., J.W. and J.Y. drafted the paper and revised it critically; R.S., M.D.C.-M., J.W., O.A., C.F.d.A.B.M., V.M., E.K., A.A., O.O. and J.Y. approved the final version to be published. All authors have read and agreed to the published version of the manuscript.

Funding: This research received no external funding.

Institutional Review Board Statement: Not applicable.

Informed Consent Statement: Not applicable.

Data Availability Statement: The data used to support the findings of this study are included within the article.

Acknowledgments: None.

Conflicts of Interest: The authors declare no conflict of interest.

\section{References}

1. Khan, A.A.; Morrison, A.; Kendler, D.L.; Rizzoli, R.; Hanley, D.A.; Felsenberg, D.; McCauley, L.K.; O’Ryan, F.; Reid, I.R.; Ruggiero, S.L.; et al. Case-Based Review of Osteonecrosis of the Jaw (ONJ) and Application of the international recommendations for management from the international task force on ONJ. J. Clin. Densitom. 2017, 20, 8-24. [CrossRef]

2. Eguia, A.; Bagán-Debón, L.; Cardona, F. Review and update on drugs related to the development of osteonecrosis of the jaw. Med. Oral Patología Oral y Cirugia Bucal 2020, 25, e71-e83. [CrossRef] [PubMed]

3. Coleman, R.; Body, J.J.; Aapro, M.; Hadji, P.; Herrstedt, J.; ESMO Guidelines Working Group. Bone health in cancer patients: ESMO Clinical Practice Guidelines. Ann. Oncol. 2014, 25, iii124-iii137. [CrossRef] [PubMed]

4. Hanley, D.A.; McClung, M.R.; Davison, K.S.; Dian, L.; Harris, S.T.; Miller, P.D.; Lewiecki, E.M.; Kendler, D.L. Western Osteoporosis Alliance Clinical Practice Series: Evaluating the Balance of Benefits and Risks of Long-Term Osteoporosis Therapies. Am. J. Med. 2017, 130, 862.e1-862.e7. [CrossRef]

5. Marx, E.R. Pamidronate (Aredia) and zoledronate (Zometa) induced avascular necrosis of the jaws: A growing epidemic. J. Oral. Maxillofac. Surg. 2003, 61, 1115-1117. [CrossRef]

6. Sacco, R.; Shah, S.; Leeson, R.; Moraschini, V.; Mourão, C.D.A.B.; Akintola, O.; Lalli, A. Osteonecrosis and osteomyelitis of the jaw associated with tumour necrosis factor-alpha (TNF- $\alpha$ ) inhibitors: A systematic review. Br. J. Oral Maxillofac. Surg. 2020, 58, 25-33. [CrossRef]

7. Sacco, R.; Ball, R.; Barry, E.; Akintola, O. The role of illicit drugs in developing medication-related osteonecrosis (MRONJ): A systematic review. Br. J. Oral Maxillofac. Surg. 2021, 59, 398-406. [CrossRef]

8. Ruggiero, S.L.; Dodson, T.B.; Fantasia, J.; Goodday, R.; Aghaloo, T.; Mehrotra, B.; O'Ryan, F. American Association of Oral and Maxillofacial Surgeons position paper on medication-related osteonecrosis of the jaw-2014 update. J. Oral. Maxillofac. Surg. 2014, 72, 1938-1956. [CrossRef]

9. Fedele, S.; Porter, S.; D’Aiuto, F.; Aljohani, S.; Vescovi, P.; Manfredi, M.; Arduino, P.G.; Broccoletti, R.; Musciotto, A.; di Fede, O.; et al. Nonexposed Variant of Bisphosphonate-associated Osteonecrosis of the Jaw: A Case Series. Am. J. Med. 2010, 123, 1060-1064. [CrossRef]

10. Aghaloo, T.; Hazboun, R.; Tetradis, S. Pathophysiology of Osteonecrosis of the Jaws. Oral Maxillofac. Surg. Clin. North Am. 2015, 27, 489-496. [CrossRef]

11. Goodwin, J.S.; Zhou, J.; Kuo, Y.-F.; Baillargeon, J. Risk of Jaw Osteonecrosis after Intravenous Bisphosphonates in Cancer Patients and Patients without Cancer. Mayo Clin. Proc. 2017, 92, 106-113. [CrossRef] [PubMed]

12. Lo, J.C.; O’Ryan, F.S.; Gordon, N.P.; Yang, J.; Hui, R.L.; Martin, D.; Hutchinson, M.; Lathon, P.V.; Sanchez, G.; Silver, P.; et al. Prevalence of Osteonecrosis of the Jaw in Patients with Oral Bisphosphonate Exposure. J. Oral Maxillofac. Surg. 2010, 68, 243-253. [CrossRef] [PubMed] 
13. Saad, F.; Brown, J.E.; Van Poznak, C.; Ibrahim, T.; Stemmer, S.M.; Stopeck, A.T.; Diel, I.J.; Takahashi, S.; Shore, N.; Henry, D.H.; et al. Incidence, risk factors, and outcomes of osteonecrosis of the jaw: Integrated analysis from three blinded active-controlled phase III trials in cancer patients with bone metastases. Ann. Oncol. 2012, 23, 1341-1347. [CrossRef]

14. Tennis, P.; Rothman, K.J.; Bohn, R.L.; Tan, H.; Zavras, A.; Laskarides, C.; Calingaert, B.; Anthony, M.S. Incidence of osteonecrosis of the jaw among users of bisphosphonates with selected cancers or osteoporosis. Pharmacoepidemiol. Drug Saf. 2012, $21,810-817$. [CrossRef] [PubMed]

15. Yamazaki, T.; Yamori, M.; Ishizaki, T.; Asai, K.; Goto, K.; Takahashi, K.; Nakayama, T.; Bessho, K. Increased incidence of osteonecrosis of the jaw after tooth extraction in patients treated with bisphosphonates: A cohort study. Int. J. Oral Maxillofac. Surg. 2012, 41, 1397-1403. [CrossRef]

16. Van den Wyngaert, T.; Wouters, K.; Huizing, M.T.; Vermorken, J.B. RANK ligand inhibition in bone metastatic cancer and risk of oste-onecrosis of the jaw (ONJ): Non bis in idem? Support Care Cancer 2011, 19, 2035-2040. [CrossRef]

17. Christodoulou, C.; Pervena, A.; Klouvas, G.; Galani, E.; Falagas, M.E.; Tsakalos, G.; Visvikis, A.; Nikolakopoulou, A.; Acholos, V.; Karapanagiotidis, G.; et al. Combination of bisphosphonates and antiangiogenic factors induces oste-onecrosis of the jaw more frequently than bisphosphonates alone. Oncology 2009, 76, 209-211. [CrossRef]

18. Al-Husein, B.; Abdalla, M.; Trepte, M.; DeRemer, D.L.; Somanath, P.R. Antiangiogenic Therapy for Cancer: An Update. Pharmacother. J. Hum. Pharmacol. Drug Ther. 2012, 32, 1095-1111. [CrossRef]

19. Diniz-Freitas, M.; Limeres, J. Prevention of medication-related osteonecrosis of the jaws secondary to tooth extractions. A systematic review. Med. Oral Patol. Oral Cir. Bucal 2016, 21, e250-e259. [CrossRef]

20. Fliefel, R.; Tröltzsch, M.; Kühnisch, J.; Ehrenfeld, M.; Otto, S. Treatment strategies and outcomes of bisphosphonate-related osteonecrosis of the jaw (BRONJ) with characterization of patients: A systematic review. Int. J. Oral Maxillofac. Surg. 2015, 44, 568-585. [CrossRef]

21. Ficarra, G.; Beninati, F. Bisphosphonate-Related osteonecrosis of the jaws: The point of view of the oral pathologist. Clin. Cases Miner. Bone Metab. 2007, 4, 53-57. [PubMed]

22. Otto, S.; Schreyer, C.; Hafner, S.; Mast, G.; Ehrenfeld, M.; Stürzenbaum, S.; Pautke, C. Bisphosphonate-related osteonecrosis of the jaws-Characteristics, risk factors, clinical features, localization and impact on oncological treatment. J. Cranio-Maxillofac. Surg. 2012, 40, 303-309. [CrossRef]

23. Mena, A.C.; Pulido, E.G.; Ponce, C.G. Understanding the molecular-based mechanism of action of the tyrosine kinase inhibitor: Sunitinib. Anti-Cancer Drugs 2010, 21, S3-S11. [CrossRef] [PubMed]

24. Otto, S.; Pautke, C.; Van den Wyngaert, T.; Niepel, D.; Schiødt, M. Medication-related osteonecrosis of the jaw: Prevention, diagnosis and management in patients with cancer and bone metastases. Cancer Treat. Rev. 2018, 69, 177-187. [CrossRef]

25. Fung, P.; Nicoletti, P.; Shen, Y.; Porter, S.; Fedele, S. Pharmacogenetics of Bisphosphonate-associated Osteonecrosis of the Jaw. Oral Maxillofac. Surg. Clin. North Am. 2015, 27, 537-546. [CrossRef]

26. Khan, A.A.; Sándor, G.K.B.; Dore, E.; Morrison, A.D.; Alsahli, M.; Amin, F.; Peters, E.; Hanley, D.A.; Chaudry, S.R.; Dempster, D.W.; et al. Canadian consensus practice guidelines for bisphosphonate associated osteonecrosis of the jaw. J. Rheumatol. 2008, 35, 1391-1397.

27. Dickinson, M.; Prince, H.M.; Kirsa, S.; Zannettino, A.; Gibbs, S.D.J;; Mileshkin, L.; O'Grady, J.; Seymour, J.F.; Szer, J.; Horvath, N.; et al. Osteonecrosis of the jaw complicating bisphosphonate treatment for bone disease in multiple myeloma: An overview with recommendations for prevention and treatment. Intern. Med. J. 2009, 39, 304-316. [CrossRef]

28. Terpos, E.; Sezer, O.; Croucher, P.; Garcia-Sanz, R.; Boccadoro, M.; Miguel, J.S.; Ashcroft, J.; Bladé, J.; Cavo, M.; Delforge, M.; et al. The use of bisphosphonates in multiple myeloma: Recommendations of an expert panel on behalf of the European Myeloma Network. Ann. Oncol. 2009, 20, 1303-1317. [CrossRef]

29. McLeod, N.; Davies, B.; Brennan, P. Management of patients at risk of bisphosphonate osteonecrosis in maxillofacial surgery units in the UK. Surg. 2009, 7, 18-23. [CrossRef]

30. Hellstein, J.W.; Adler, R.A.; Edwards, B.; Jacobsen, P.L.; Kalmar, J.R.; Koka, S.; Migliorati, C.A.; Ristic, H. American Dental Association Council on Scientific Affairs Expert Panel on Antiresorptive Agents. Managing the care of patients receiving antiresorptive therapy for prevention and treatment of osteoporosis: Executive summary of recommendations from the American Dental Association Council on Scientific Affairs. J. Am. Dent. Assoc. 2011, 142, 1243-1251.

31. Snowden, J.A.; Ahmedzai, S.H.; Ashcroft, J.; D’Sa, S.; Littlewood, T.; Low, E.; Lucraft, H.; Maclean, R.; Feyler, S.; Pratt, G.; et al. Haemato-oncology Task Force of British Committee for Standards in Haematology and UK Myeloma Forum. Guidelines for supportive care in multiple myeloma. Br. J. Haematol. 2011, 154, 76-103. [CrossRef]

32. Khan, A.A.; Morrison, A.; Hanley, D.A.; Felsenberg, D.; McCauley, L.K.; O’Ryan, F.; Reid, I.R.; Ruggiero, S.L.; Taguchi, A.; Tetradis, S.; et al. Diagnosis and Management of Osteonecrosis of the Jaw: A Systematic Review and International Consensus. J. Bone Miner. Res. 2015, 30, 3-23. [CrossRef] [PubMed]

33. Kim, K.M.; Rhee, Y.; Kwon, Y.-D.; Kwon, T.-G.; Lee, J.K.; Kim, D.-Y. Medication Related Osteonecrosis of the Jaw: 2015 Position Statement of the Korean Society for Bone and Mineral Research and the Korean Association of Oral and Maxillofacial Surgeons. J. Bone Metab. 2015, 22, 151-165. [CrossRef]

34. Svejda, B.; Muschitz, C.; Gruber, R.; Brandtner, C.; Svejda, C.; Gasser, R.W.; Santler, G.; Dimai, H.P. Position paper on med-icationrelated osteonecrosis of the jaw (MRONJ). Wien. Med. Wochenschr. 2016, 166, 68-74. [CrossRef] 
35. Japanese Allied Committee on Osteonecrosis of the Jaw; Yoneda, T.; Hagino, H.; Sugimoto, T.; Ohta, H.; Takahashi, S.; Soen, S.; Taguchi, A.; Nagata, T.; Urade, M.; et al. Antiresorptive agent-related osteonecrosis of the jaw: Position Paper 2017 of the Japanese Allied Committee on Osteonecrosis of the Jaw. J. Bone Miner. Metab. 2016, 35, 6-19. [CrossRef] [PubMed]

36. Scottish Dental Clinical Effectiveness Programme. Oral health management of patients at risk of medication-related osteone-crosis of the jaw. Br. Dent. J. 2017, 222, 930. [CrossRef] [PubMed]

37. Moraschini, V.; Calasans-Maia, M.D.; Louro, R.S.; Arantes, E.B.; Calasans-Maia, J.D. Weak evidence for the management of medication-related osteone-crosis of the jaw: An overview of systematic reviews and meta-analyses. J. Oral. Pathol. Med. 2021, 50, 10-21. [CrossRef] [PubMed]

38. Liberati, A.; Altman, D.G.; Tetzlaff, J.; Mulrow, C.; Gøtzsche, P.C.; Ioannidis, J.P.A.; Clarke, M.; Devereaux, P.; Kleijnen, J.; Moher, D. The PRISMA statement for reporting systematic reviews and meta-analyses of studies that evaluate healthcare interventions: Explanation and elaboration. BMJ 2009, 339, b2700. [CrossRef]

39. Schardt, C.; Adams, M.B.; Owens, T.; Keitz, S.; Fontelo, P. Utilization of the PICO framework to improve searching PubMed for clinical questions. BMC Med. Inform. Decis. Mak. 2007, 7, 16. [CrossRef]

40. Aljohani, S.; Fliefel, R.; Ihbe, J.; Kühnisch, J.; Ehrenfeld, M.; Otto, S. What is the effect of anti-resorptive drugs (ARDs) on the development of medication-related osteonecrosis of the jaw (MRONJ) in osteoporosis patients: A systematic review. J. CranioMaxillofac. Surg. 2017, 45, 1493-1502. [CrossRef]

41. Beth-Tasdogan, N.H.; Mayer, B.; Hussein, H. Interventions for managing medication-related osteonecrosis of the jaw (MRONJ). Cochrane Database Syst. Rev. 2016, 6, CD012432. [CrossRef]

42. Cabras, M.; Gambino, A.; Broccoletti, R.; Sciascia, S.; Arduino, P.G. Lack of evidence in reducing risk of MRONJ after teeth extractions with systemic antibiotics. J. Oral Sci. 2021, 63, 217-226. [CrossRef]

43. Prá, K.D.; Lemos, C.; Okamoto, R.; Soubhia, A.; Pellizzer, E. Efficacy of the C-terminal telopeptide test in predicting the development of bisphosphonate-related osteonecrosis of the jaw: A systematic review. Int. J. Oral Maxillofac. Surg. 2017, 46, 151-156. [CrossRef]

44. Duarte, N.T.; Rech, B.D.O.; Martins, I.G.; Franco, J.B.; Ortega, K.L. Can children be affected by bisphosphonate-related osteonecrosis of the jaw? A systematic review. Int. J. Oral Maxillofac. Surg. 2020, 49, 183-191. [CrossRef]

45. Gelazius, R.; Poskevicius, L.; Sakavicius, D.; Grimuta, V.; Juodzbalys, G. Dental implant placement in patients on bisphosphonate therapy: A systematic review. J. Oral. Maxillofac. Res. 2018, 9, e2. [CrossRef]

46. Govaerts, D.; Piccart, F.; Ockerman, A.; Coropciuc, R.; Politis, C.; Jacobs, R. Adjuvant therapies for MRONJ: A systematic review. Bone 2020, 141, 115676. [CrossRef]

47. Hennedige, A.A.; Jayasinghe, J.; Khajeh, J.; Macfarlane, T.V. Systematic Review on the Incidence of Bisphosphonate Related Osteonecrosis of the Jaw in Children Diagnosed with Osteogenesis Imperfecta. J. Oral Maxillofac. Res. 2013, 4, e1. [CrossRef]

48. Hess, L.M.; Jeter, J.M.; Benham-Hutchins, M.; Alberts, D.S. Factors Associated with Osteonecrosis of the Jaw among Bisphosphonate Users. Am. J. Med. 2008, 121, 475-483.e3. [CrossRef]

49. Lorenzo-Pouso, A.I.; Pérez-Sayáns, M.; Chamorro-Petronacci, C.; Vila, P.G.; López-Jornet, P.; Carballo, J.; García-García, A. Association between periodontitis and medication-related osteonecrosis of the jaw: A systematic review and meta-analysis. J. Oral Pathol. Med. 2020, 49, 190-200. [CrossRef]

50. Lorenzo-Pouso, A.I.; Pérez-Sayáns, M.; González-Palanca, S.; Chamorro-Petronacci, C.; Bagán, J.; García-García, A. Bi-omarkers to predict the onset of biphosphonate-related osteonecrosis of the jaw: A systematic review. Med. Oral. Patol. Oral. Cir. Bucal. 2019, 24, e26-e36. [PubMed]

51. Madrid, C.; Sanz, M. What impact do systemically administrated bisphosphonates have on oral implant therapy? A system-atic review. Clin. Oral. Implants Res. 2009, 4, 87-95. [CrossRef]

52. Mauri, D.; Valachis, A.; Polyzos, I.P.; Polyzos, N.P.; Kamposioras, K.; Pesce, L.L. Osteonecrosis of the jaw and use of bisphosphonates in adjuvant breast cancer treatment: A meta-analysis. Breast Cancer Res. Treat. 2009, 116, 433-439. [CrossRef]

53. McGowan, K.; McGowan, T.; Ivanovski, S. Risk factors for medication-related osteonecrosis of the jaws: A systematic review. Oral Dis. 2018, 24, 527-536. [CrossRef]

54. Migliorati, C.A.; Woo, S.B.; Hewson, I.; Barasch, A.; Elting, L.S.; Spijkervet, F.K.; Brennan, M.T. Bisphosphonate Osteonecrosis Section, Oral Care Study Group, Multinational Association of Supportive Care in Cancer (MASCC)/International Society of Oral Oncology (ISOO). A systematic review of bisphosphonate osteonecrosis (BON) in cancer. Support Care Cancer 2010, 18, 1099-1106. [CrossRef] [PubMed]

55. Ottesen, C.; Schiodt, M.; Gotfredsen, K. Efficacy of a high-dose antiresorptive drug holiday to reduce the risk of medica-tionrelated osteonecrosis of the jaw (MRONJ): A systematic review. Heliyon 2020, 6, e03795. [CrossRef]

56. Palaska, P.K.; Cartsos, V.; Zavras, A.I. Bisphosphonates and time to osteonecrosis development. Oncologist 2009, 14, 1154-1166. [CrossRef] [PubMed]

57. Querrer, R.; Ferrare, N.; Melo, N.; Stefani, C.M.; Dos Reis, P.E.D.; Mesquita, C.R.M.; Borges, G.A. Differ-ences between bisphosphonate-related and denosumab-related osteonecrosis of the jaws: A systematic review. Support Care Cancer 2021, 29, 2811-2820. [CrossRef]

58. Rollason, V.; Laverrière, A.; MacDonald, L.C.; Walsh, T.; Tramèr, M.R.; Vogt-Ferrier, N.B. Interven-tions for treating bisphosphonate-related osteonecrosis of the jaw (BRONJ). Cochrane Database Syst. Rev. 2016, 2, CD008455. 
59. Sacco, R.; Woolley, J.; Yates, J.; Calasans-Maia, M.D.; Akintola, O.; Patel, V. The role of antiresorptive drugs and medica-tionrelated osteonecrosis of the jaw in nononcologic immunosuppressed patients: A systematic review. J. Res. Med. Sci. 2021, 26, 23. [CrossRef]

60. Sacco, R.; Woolley, J.; Yates, J.; Calasans-Maia, M.D.; Akintola, O.; Patel, V. A systematic review of metastatic cancer pre-senting in osteonecrosis of the jaws (MC-ONJ) in patients undergoing antiresorptive and/or antiangiogenic therapy for skele-tal-related adverse events. Oral. Surg. Oral. Med. Oral. Pathol. Oral. Radiol. 2021, 131, 650-659. [CrossRef]

61. Sacco, R.; Woolley, J.; Patel, G.; Calasans-Maia, M.D.; Yates, J. A systematic review of medication related osteonecrosis of the jaw (MRONJ) in patients undergoing only antiangiogenic drug therapy: Surgery or conservative therapy? Br. J. Oral Maxillofac. Surg. 2021. [CrossRef]

62. de Souza Tolentino, E.; de Castro, T.F.; Michellon, F.C.; Passoni, A.C.C.; Ortega, L.J.A.; Iwaki, L.C.V.; da Silva, M.C. Adju-vant therapies in the management of medication-related osteonecrosis of the jaws: Systematic review. Head Neck 2019, 41, 4209-4228. [CrossRef]

63. Woo, S.-B.; Hellstein, J.W.; Kalmar, J.R. Systematic Review: Bisphosphonates and Osteonecrosis of the Jaws. Ann. Intern. Med. 2006, 144, 753. [CrossRef] [PubMed]

64. Woolley, J.; Akintola, O.; Yates, J.; Calasans-Maia, M.D.; Calasans-Maia, J.D.A.; Kocherhina, I.; Sacco, R. The risk of osteonecrosis of the jaw and adverse outcomes in patients using antiresorptive drugs undergoing orthodontic treatment: A systematic review. Heliyon 2021, 7, e05914. [CrossRef] [PubMed]

65. Lewin, S.; Glenton, C.; Munthe-Kaas, H.; Carlsen, B.; Colvin, C.J.; Gülmezoglu, M.; Noyes, J.; Booth, A.; Garside, R.; Ra-shidian, A. Using qualitative evidence in decision making for health and social interventions: An approach to assess confi-dence in findings from qualitative evidence syntheses (GRADE-CERQual). PLoS Med. 2015, 12, e1001895. [CrossRef] [PubMed]

66. King, R.; Tanna, N.; Patel, V. Medication-related osteonecrosis of the jaw unrelated to bisphosphonates and denosumab-A review. Oral Surg. Oral Med. Oral Pathol. Oral Radiol. 2019, 127, 289-299. [CrossRef]

67. Wat, W.Z.M. Current Controversies on the Pathogenesis of Medication-Related Osteonecrosis of the Jaw. Dent. J. 2016, 4, 38. [CrossRef] [PubMed]

68. Oxford Centre for Evidence-Based Medicine. 2009. Available online: https://www.cebm.ox.ac.uk/resources/levels-of-evidence/ oxford-centre-for-evidence-based-medicine-levels-of-evidence-march-2009 (accessed on 1 June 2021). 